J. Chemical studies on memon fixition in goldfish. Brain Research. 1966. 1. 303-309.

BRINK. J. J., DAVIS, R. E., \& AGRA IOI I. B. W. Effects of purom ysin. acetoxycycloheximide and actinomycin $\mathrm{D}$ on protein synthesis in goldfish brain 5 . Journal of Neurochemistry, 1966, 13,889-896.

COHEN, H. D.. \& BARONDES, S. H. Puromycin effect on memory may be due to occult seizures. Science. 1967, 157, 333-334.

COHEX. H. D., ERVIN, F., \& BARONDFS. S. H. Puromycin and cycloheximide: Different effects on hippocampal electrical activity. Science. 1966, 154, 1557-1558.

DAVIS, R. E.. BRIGHT, P. J.. \& AGRANOFF, B. W. Fffect of ECS and puromycin on memory in fish. Journal of Comparative \& Physiological Pyychology, 1965, 60, 162-166.
ILIXNER, J, B.. FLEXIER, L, B, STELIAR, 1.. de la HABA, G.. \& ROBERTS, R. B. Inhibition of protein synthesis in brain and liaming and memory following puromycin. Journal of Veurachemistry, 1962, 9, 595-605. POTTS, 4., \& BITTERMAN, M. E. Puromycin and retention in goldfish. Science, 1967,158 , 1694-1696.

SIEKEVITZ. P. Lptake of radioactive alanine in vitro into the proteins of rat liver fractions. Joumal of Biological Chemistry, 1952, 195, 549-565.

\section{NOTE}

1. Fish No. 33 was reinforced only for the 30 responses completed in the first $5 \mathrm{~min}$. The rate was therefore taken to be 30 responses per $5 \mathrm{~min}$ or 6 responses per minute.

\title{
Self-punitive locomotor behavior in the Mongolian gerbil
}

\author{
R. CHRIS MARTIN \\ University of Missouri-Kansas City, Kansas City, Mo. 64110 \\ EVELYN RAGLAND \\ Hollins College, Hollins, Va. 24020 \\ and \\ KENNETH B. MELVIN \\ University of Alabama, University, Ala. 35486
}

This study was primarily a test of the generality of a behavioral phenomenon across species. Several investigations have shown that rats when punished for an aversively motivated response will maintain that response rather than abandon it. Similar treatments revealed that the Mongolian gerbil also showed such self-punitive behavior. Special characteristics of the gerbil were noted.

Punishment of an ongoing aversively motivated response may maintain, or even facilitate, performance (e.g., Brown,

\footnotetext{
* This research was supported in part by a gran to the first author from $\mathrm{Mr}$. F. Ot to Haas of the Haas Foundation, and in part by Grant 2189-2100 from LMKC to the first author.
}

Martin, \& Morrow, 1964; Melvin \& Martin, 1966). A number of investigators have studied this "vicious-circle" phenomenon through the analysis of locomotor behavior in the rat (see Brown, 1969). In fact, rats of various strains have been used in such studies. Recently, however, the generality of behavioral principles derived by use of laboratory rats has been severely questioned (Lockard, 1968). While one may not agree with many of Lockard's contentions, his article does emphasize the need for more studies that examine the generality of phenomena across species. In the present study treatment conditions of punishment-after-escape training were instituted during extinction of a runway response in an attempt to ascertain whether the gerbil species of the order Rodentia demonstrate "vicious-circle" behavior.

Gerbils differ from rats (especially laboratory rats) in many respects, e.g. their ecological niche, water intake, resistance to heat, type of habitat, and the discovery that a behavioral phenomenon found in rats is also shown by the gerbil would broaden the generality of that phenomenon significantly.

\section{SUBJECTS AND APPARATUS}

The Ss, 14 naive male gerbils (Meriones unguiculatus) of the Tumblebrook strain, were 13-14 weeks old, All Ss were deprived of food for $23 \mathrm{~h}$ before training.

The apparatus was a straight runway, 82 in. long and 12 in. high. A guillotine door, 12 in. from one end, divided the runway into a startbox and an alley 70 in. in length. At the other end of the runway, a second guillotine door separated the goalbox from the alley. The goalbox was $12 \times 18 \times 13.5$ in., painted black, and had a wooden floor and lid. In contrast, the startbox and alley were white, had floors consisting of $1 / 4$-in.-diam grid rods spaced $3 / 4$ in. apart, and had lids of Plexiglas.

Raising the doors turned on the shock and an electronic clock; this clock stopped and a second clock started when $S$ interrupted a photobeam 7 in. outside the startbox. The second clock stopped when $S$ broke a photobeam at the entrance of the goalbox, thus measuring alley time to the nearest $.01 \mathrm{sec}$.

\section{PROCEDURE}

Shock-escape training consisted of eight shaping trials followed by 35 acquisition trials. During shaping $S$ was placed onto the grid at successive distances of $1.5,3.0$, 4.5 , and $6 \mathrm{ft}$ from the goalbox. Each gerbil was given two trials for each distance. Between each trial $S$ remained in the goalbox for approximately $30 \mathrm{sec}$. The intensity of the scrambled shock was $1.0 \mathrm{~mA}$

During acquisition $S$ was placed in the startbox. The doors were then raised, turning on a $1.0-\mathrm{mA}$ shock. When $\mathrm{S}$ entered the goalbox, the doors were lowered to prevent retracing, and $S$ remained there for about $20 \mathrm{sec}$. The intertrial interval was approximately $30 \mathrm{sec}$. 


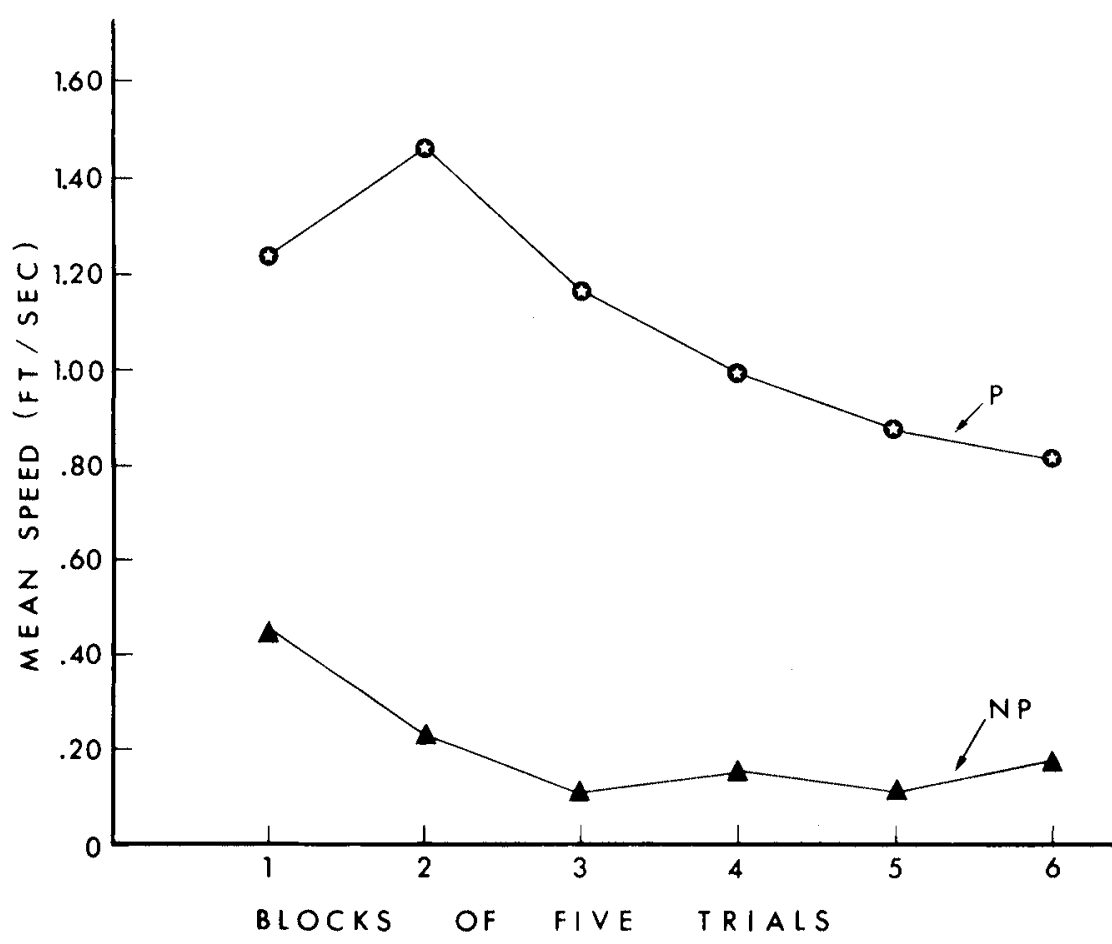

Fig. 1. Mean speed in feet per second for punished and nonpunished groups across blocks of five trials during extinction.

Immediately following acquisition, $\mathrm{S}$ received extinction trials. For Group $P$ shock $(1.0 \mathrm{~mA})$ was present only on the first 18 in. of grid immediately in front of the startbox. Group NP served as the nonpunished control group, i.e., shock was no longer present in any part of the apparatus. During extinction, shock was never present in the startbox under either condition. Seven gerbils were randomly assigned to each condition. Provided $S$ continued to run, a total of 100 extinction trials were given. If $S$ failed to enter the goalbox within $60 \mathrm{sec}$ on two consecutive trials, testing ceased, and arbitrary scores of $60 \mathrm{sec}$ were recorded for that $\mathrm{S}$.

\section{RESULTS}

The mean number of trials to extinction was 49.7 for Group $P$ and 22.1 for Group NP. This large mean difference, however, only approached statistical significance $(t=1.81 ; .05<\mathrm{p}<.01)$. Similarly, the median number of trials to extinction was 36 for Group P and only 17 for Group NP, but a Mann-Whitney U test was nonsignificant $(\mathrm{U}=12, \mathrm{P}=.13) .^{1}$ Two punished gerbils (Group P) were the only Ss that ran the limit of 100 trials.

Figure 1 shows the mean alley speed for each group over six blocks of five extinction trials. Clearly, the punished $\mathrm{S}$ ran faster than $S$ s given regular extinction (Group NP). Analysis of variance of these delay," exhibited much higher resistance to extinction (mean number of trials $=83$ ) than our Group P

A closer look at both apparatus and gerbil. however. reveals two factors that probably reduced the effects of the present treatment condition. With considerable hindsight, we now conclude that these factors were (1) the "mild" behavioral effects of a 1-mA shock on gerbils and (2) the excessive size of the apparatus, relative to the size of the gerbil. The $1-\mathrm{mA}$ shock did evoke escape, but $\mathrm{S}$ did not show high speeds. A simple explanation lies in the fact that gerbils have hairy feet; a simple solution to the problem is the application of a depilatory to $S$ 's feet 1 day before training.

The second factor of apparatus size seems equally important. In fact, a comparison of the two species in terms of body lengths in the runway demonstrates this apparatus/subject size inequity. Thus the present situation seems analogous to testing rats in a wide, $12 \cdot \mathrm{ft}$ alley, a procedure that can be expected to increase response variability since there are more "incorrect" places for the S to visit. Our observations revealed that gerbils in both groups tended to slow dramatically in the last one-fourth of the alley. A 3- to 4- $\mathrm{ft}$ narrow alley or a lever-press situation is recommended for future studies

With the above modifications, we predict that gerbils will exhibit strong self-punitive locomotor behavior, as has been shown in rats. Even with the present methodology, the significant punishment-induced facilitation of running speed indicated that the vicious-circle phenomenon is not limited to the domestic version of Rattus norvegicus.

\section{REFERENCES}

BROWN, J. S. Factors influencing self-punitive locomotor behavior. In B. A. Campbell and R. M. Church (Eds.), Punishment and aversive behavior. New York: Appleton-CenturyCrofts, 1969. Pp. 000-000.

BROWN, J.S., MARTIN, R. C., \& MORROW, M. W. Self-punitive behavior in the rat: Facilitative effects of punishment on resistance to extinction. Journal of Comparative \& Physiological Psychology, 1964, 57, 127-133.

LOCKARD, R. B. The albino rat: A defensible choice or a bad habit? American Psychologist, 1968, 23, 734-741.

MARTIN, R. C., Self-punitive behavior: One way to stop it. Psychonomic Science, 1969, 14 , 25-26.

These data indicate that the vicious-circle phenomenon may be obtained with gerbils as Ss. However, despite our use of "optimal" conditions, the self-punitive effect was weak relative to that obtained with rats under comparable circumstances (cf. Martin, 1969; Melvin, Athey, \& Heasley, 1965). For example, Martin (1969) used a similar alley, training procedure, shock intensity, and location. His equivalent punished group, "VC-no

MELVIN, K. B., \& MARTIN, R. C. Facilitative effects of two modes of punishment on resistance to extinction. Journal of Comparative \& Physiological Psychology, $1966,62,491-494$.

MELVIN, K. B., ATHEY, G. I., JR., \& HEASLEY, F. H. Effects of duration and delay of shock on self-punitive behavior in the rat. Psychological Reports, 1965, 17, 107-112. NOTE:

1. All statistical tests are two-tailed. 